\title{
SU KİRLİLíĞi AÇISINDAN HASSAS ALANLARIN İZLENMESi̇: KIZILIRMAK DELTASI-BALIK GÖLÜ
}

\author{
Sema ARIMAN ${ }^{*}$, Serdar KOYUNCU² \\ ${ }^{1}$ Samsun Üniversitesi, Havacılık ve Uzay Bilimleri Fakültesi, Meteoroloji Mühendisliği Bölümü, Samsun, \\ Türkiye \\ ${ }^{2}$ Konya Büyükșehir Belediyesi, KOSKİ Genel Müdürlüğü, Konya, Türkiye
}

\begin{tabular}{|c|c|}
\hline Anahtar Kelimeler & Öz \\
\hline Kızılırmak Deltası & Kızılırmak Deltası'ndaki hassas alan olan Balık gölünün su \\
\hline Balık Gölü, & kalitesindeki değişiklik zamansal olarak izlenmiș ve gölün trofik durumu (yașam \\
\hline Hassas Alan, & evresi) belirlenmeye çalıșılmıștır. Balık Gölü'nün su kalitesini belirlemek için \\
\hline Su Kalitesi, & arazide/anlık olarak, seki disk derinliği (SDD), sıcaklık, pH, elektriksel iletkenlik, \\
\hline Trofik Seviye Indeksi. & çözünmüş oksijen, laboratuvar ortamında ise klorofil a, Renkli Çözünmüş Organik \\
\hline & Madde (CDOM), toplam fosfor (TP), toplam azot (TN), toplam çözünmüş katı (TDS), \\
\hline & tuzluluk ve bulanıklık gibi analizler gerçekleştirilmiștir. Ayrıca, Trofik Seviye \\
\hline & kriter/indekslerine göre seki disk derinliği, klorofil a (Chl-a), toplam fosfor ve \\
\hline & Trofik Seviye İndeks (Calson 1977) sınıflandırmasına göre, mevsimsel değișimlere \\
\hline & bağlı olarak, TP,TN, SDD ve Chl-a'nın, ötrofik durumun sınır değerini aştığı (TSI 60- \\
\hline & $\begin{array}{l}\text { 70), hipertrofik durumun yaygın olması nedeniyle gölün kritik durumda olduğu } \\
\text { belirlenmiștir. }\end{array}$ \\
\hline
\end{tabular}

\section{MONITORING OF SENSITIVE AREAS FOR WATER POLLUTION: KIZILIRMAK DELTA- BALIK LAKE}

\author{
Keywords \\ Kızılırmak Deltas \\ Balık Lake, \\ Sensitive Area, \\ Water Quality, \\ Trophic Level Index.
}

\begin{abstract}
In this study, the seasonal changes in the water quality of the Balık Lake, which is the sensitive area in the Kizılirmak Delta, were monitored temporally and the trophic status (life phase) of the lake was investigated. In order to determine the water quality of the Balık Lake, the Secchi disk depth (SDD), temperature, $\mathrm{pH}$, Electrical Conductivity (EC), Dissolved Oxygen (DO) were analyzed in the field; and the chlorophyll a (Chl-a), Color Dissolved Organic Matter (CDOM), Total Phosphorus (TP), Total Nitrogen (TN), Total Dissolved Solids (TDS), salinity and turbidity were studied in the laboratory. In addition, the trophic status of the lake was determined by using the Secchi disk depth, chlorophyll a, total phosphorus and total nitrogen parameter values according to the trophic level criteria / indices. According to the Trofik Level Index classification (Carlson 1977), the TP, TN, SDD and Chl-a exceed the limit value of eutrophic condition (TSI 60-70) depending on the seasonal changes and the lake is in critical condition due to the prevalent hypertrophic status.
\end{abstract}

\section{Alıntı / Cite}

Arıman, S., Koyuncu, S., (2019). Su Kirliliği Açısından Hassas Alanların İzlenmesi: Kızılırmak Deltası-Balık Gölü, Mühendislik Bilimleri ve Tasarım Dergisi, 7(4), 705-714.

\begin{tabular}{l|l}
\hline Yazar Kimliği / Author ID (ORCID Number) & Makale Süreci / Article Process
\end{tabular}

S. Arıman, 0000-0001-7201-9243

S. Koyuncu, 0000-0002-4757-4680
Başvuru Tarihi / Submission Date $\quad$ 22.02.2019

Revizyon Tarihi / Revision Date

Kabul Tarihi / Accepted Date

Yayım Tarihi / Published Date
22.02 .2019
09.05 .2019

10.05 .2019

19.12.2019

\footnotetext{
* ilgili yazar / Corresponding author: sema.ariman@samsun.edu.tr, +90-362-312-1919-7665
} 


\section{Giriş}

Geçtiğimiz yüzyılda, artan șehirleșme ve evsel atık su artışı, sulak alanların ve nehirlerin regülasyonu, artan tarım ve hayvancılık faaliyetleri çoğu sığ gölde besin tuzu yüklemesini (özellikle azot ve fosfor) arttırmış ve ötrofikasyon problemine yol açmıştır (Jeppese 1998). Göllerde aşırı azot ve fosfor yükleri alg patlamasının şiddetini artırmaktadır. Zaman içerisinde, alg ve bitkilerin ölmesi sonucu oluşan organik maddenin bakteriler ile parçalanması sonucu hızla harcanan oksijen nedeni ile su içerisindeki oksijen azalmakta olup, bu da suda oksijene ihtiyaç duyan balıklar bașta olmak üzere diğer türlerin zarar görmesine neden olmaktadır (Le vd., 2010).

Avrupa Topluluğu tarafindan kabul edilen 'Su Çerçeve Direktifi' (SÇD) doğrultusunda Avrupa'daki sucul ekosistemler ve bunlara bağlı diğer ekosistemlerin ekolojik olarak iyi duruma gelmesini sağlamak amacıyla çalışmalar yürütülmektedir (WFD 2000). Türkiye'de ise Yerüstü Su Kalitesi Yönetmeliği (YSKY) su kalitesi yönetimine ilişkin kapsamlı düzenlemeler getirmiştir. Bu yönetmelikte, yerüstü sular ile kıyı ve geçiş sularının biyolojik, kimyasal, fiziko-kimyasal ve hidromorfolojik kalitelerinin belirlenmesi, sinıflandırılması, su kalitesinin ve miktarının izlenmesi, bu suların kullanım maksatlarının sürdürülebilir kalkınma hedefleriyle uyumlu bir şekilde koruma kullanma dengesi de gözetilerek ortaya konulması, korunması ve iyi su durumuna ulaşılması için alınacak tedbirler belirlenmiştir (YSKY 2016).Türkiye'de tatlı su havzalarının çoğu koruma altında olmayıp evsel, endüstriyel ve tarımsal kirlilik kaynaklarının alıcı ortamları şeklindedir. SÇD (2000) ve YSKY (2016)'nin hedefleri doğrultusunda, tatlı su kaynaklarımızın özelliklerinin belirlenmesi, alıcı ortamlarda öngörülen su kalitesi ve ekolojik statüye ulaşmasına imkan verecek tarzda uygun 'Su kalitesi İzlenme Çalışmaları' yapılması gerekliliği açıkça ortaya çıkmaktadır. Türkiye'de Yerüstü Su Kalitesi Yönetmeliği hazırlanmasıyla, su kalitesi yönetimine ilişkin kapsamlı düzenlemeler getirilerek, ekosistem prensibi çerçevesinde su kalitesinin korunması ve ülke gereksinimleri doğrultusunda su kalitesinin geliştirilmesi ve sürdürülebilir su yönetimi hedeflenmiştir. Öte yandan, günümüzde artan şehirleşme ve sanayileşme sonucunda evsel ve endüstriyel atık su miktarında artıș, sulak alanların ve nehirlerin regülasyonları, bilinçsiz tarım ve hayvancılık faaliyetlerinin yürütülmesi, taban suyu ve drenaj kanalları vasıtasıyla ekosistem ciddi anlamda azot, fosfor ve potasyum yüklemesine maruz kalmakla birlikte bu durum birçok sulak alan gibi Kızılırmak Deltası için de tehlike arz etmeye başlamıştır. Hatta arazi kullanımındaki değişiklikler, sulama ile drenaj kanallarındaki yenilikler ve balıkçılık benzeri faaliyetler deltadaki sulak alanları doğrudan etkileyerek ekosistem içerisindeki biyoçeşitlilik yok olma tehlikesi ile karşı karşıya bulunmaktadır
(Yeniyurt vd., 2011. Bu nedenle Türkiye'de özellikle sulak alanlardaki kirlenme kaynaklı tehlikelerin sistematik bir şekilde izlenmesi, tespit edilmesi durumunda vakit geçirmeden gerekli müdahalenin ve/veya önlemlerin alınması, geleceğe dair planlamaların yapılması benzer doğa güzelliklerinin korunması açısından önem arz etmektedir.

Kızılırmak Deltası, 1998 yılında 'Ramsar Alanı' içine giren, 'Uluslararası öneme sahip alan' özelliği taşıyan ve Karadeniz Bölgesi'ndeki tek sulak alandır. Deltanın toplam alanı 56000 ha olup, barındırdığı sulak alanların büyüklüğü ise 16110 ha'dır. Delta alanında, birinci, ikinci ve üçüncü derece doğal sit alanları, irili ufaklı sulak bölgeler ve yaban hayatı geliştirme sahaları bulunmaktadır. Deltanın, Karadeniz'e özgü nadir habitat türlerini içermesi, çok sayıda nesli tehlike altında olan bitki, hayvan ve balık (mersin balığı gibi) türüne ev sahipliği yapması, çok sayıda canlı türünün Karadeniz'deki en önemli yaşam alanlarından biri olması, birçok kuş ve iç su balığı türünün hayatlarının belirli dönemlerini geçirdikleri alan olması, yıl boyunca 20 binden fazla su kuşu barındırması önemini daha da arttırmaktadır (Orman Su işleri Bakanlığı 2013).

Kızılırmak Deltası'nın her iki yakasında deniz kıyısına paralel olarak uzanan sulak alanlar bulunmaktadır. Batı ve doğu sahilinde delta ve kıyı oluşumunu meydana getiren doğal şartlar farklı büyüklüklerde göllerin meydana gelmesini sağlamıştır. Lagün (kıyı göl) özelliği gösteren bu göllerin arasında çok sayıda küçük ve geçici su havzaları yaz aylarında kurumaktadır. Ayrıca bu sulak alanların birçoğu günümüzde, farklı arazi kullanımları (tarımsal vb.), hidrolojik değișimler (sulama ve drenaj kanalları gibi) ve balıkçlılk benzeri insan faaliyetlerinin etkisi altında biçim değiştirmiştir. Bu çalışma kapsamında çalışma alanı olarak seçilen ve 1389 hektarlık alana sahip olan Balık Gölü, bu göller içerisinde en büyük yüzey alanına sahip olan göldür (Şekil 1). Kıyısal göllerden biri olan ve Deltanın doğu yakasında yer alan Balık Gölü, 19 Mayıs beldesi (Bafra-Samsun) sınırları içerisinde yaklaşık 1380 ha'lık alanı kaplamaktadır. Balık Gölü'nün denizle bağlantısı olduğundan, diğer göllere göre daha tuzlu olup, göl derinliği 3 m'ye kadar çlkmaktadır (SKDYP, 2019).

Su kaynaklarının havza ölçeğinde bütünleşik yönetim yaklașımı ile SÇD çerçevesinde su kalitesinin arttırılması hedeflenmekte ve halen devam etmekte olan AB Mevzuatı'na uyum süreci ve bu süreçte söz konusu olan SÇD'ye uyum çalışmaları çerçevesinde su kaynaklarının havza ölçeğinde yönetimi prensibi benimsenmektedir. Bu kapsamda havza koruma planları hazırlanmakta ve noktasal ve yayılı kaynaklı kirleticiler (konvansiyonel, tehlikeli maddeler veya mikro-kirleticiler) birlikte değerlendirilerek su kütleleri korunmaya ya da kalitesinin arttırılması hedefine ulaşılmaya çalışılmaktadır. $\mathrm{Bu}$ amaç doğrultusunda ekolojik ve kimyasal durumun tespiti 
için fizikokimyasal, kimyasal, biyolojik ve hidromorfolojik parametrelerin izlenmesi, değerlendirilmesi ve su kalitesinin iyileştirilmesi için gerekli tedbirlerin alınması gerekmektedir. $\mathrm{Bu}$ çalışmada, Kızılırmak Deltası gibi uluslararası koruma statüsü içerisinde bulunan en büyük göllerden biri olan Balık Gölünün hassas alan olması nedeniyle su kalitesini izleme çalışmaları yürütülerek gölün su kalitesi durumu ve trofik seviyesi belirlenmeye çalışılmıştır.

\section{Materyal ve Metot}

\section{1. Çalışma Alanı ve Örnekleme Çalışması}

$\mathrm{Bu}$ çalışma kapsamında, göl yüzeyindeki örnekleme çalışmaları, Nisan-2017- Nisan 2018 tarihleri arasında 10 farklı noktadan aylık olarak ilkbahar, yaz, sonbahar kıș mevsimlerinde yapılmıștır (Şekil 1). Gölde örnek alma noktaları,"Su Kirliliği Kontrol Yönetmeliği
Numune Alma ve Analiz Metodları Tebliği (R.G:10.10.2009/ 27372)"ne uygun olarak belirlenmiştir. Ayrıca, ölçüm noktaları seçilirken her bir örnekleme noktasının gölün su kalitesini temsil edecek şekilde kuzey-güney yönünde birbirinden yaklaşık $1 \mathrm{~km}$ uzaklıktaki 5 ayrı nokta seçilmesi uygun görülmüş ve toplamda 5 x 2'lik bir grid yapısında 10 istasyon belirlenmiştir. Göl suyundan örneklerin alınma ve korunma yöntemleri "İç alanlarda Göl suyu örnekleme Kılavuzu'nda belirtilen yöntemlere göre yapılmıştır (EPA, 2010). Göl suyundan alınan örnekler, su yüzeyinin 0,2-0,3 m altından alınmıştır. 10 farklı noktadan alınan örnekleme noktalarına ait, koordinat bilgileri (enlem-boylam) ile birlikte alınan örnekler etiketlenerek, analizler yapılmak üzere her bir parametre için uygun olan korunma yöntemlerine göre saklanmıştır. Suyun fizikokimyasal analizleri Meteoroloji Mühendisliği Bölümü Genel Kimya laboratuvarında gerçekleştirilmiştir.

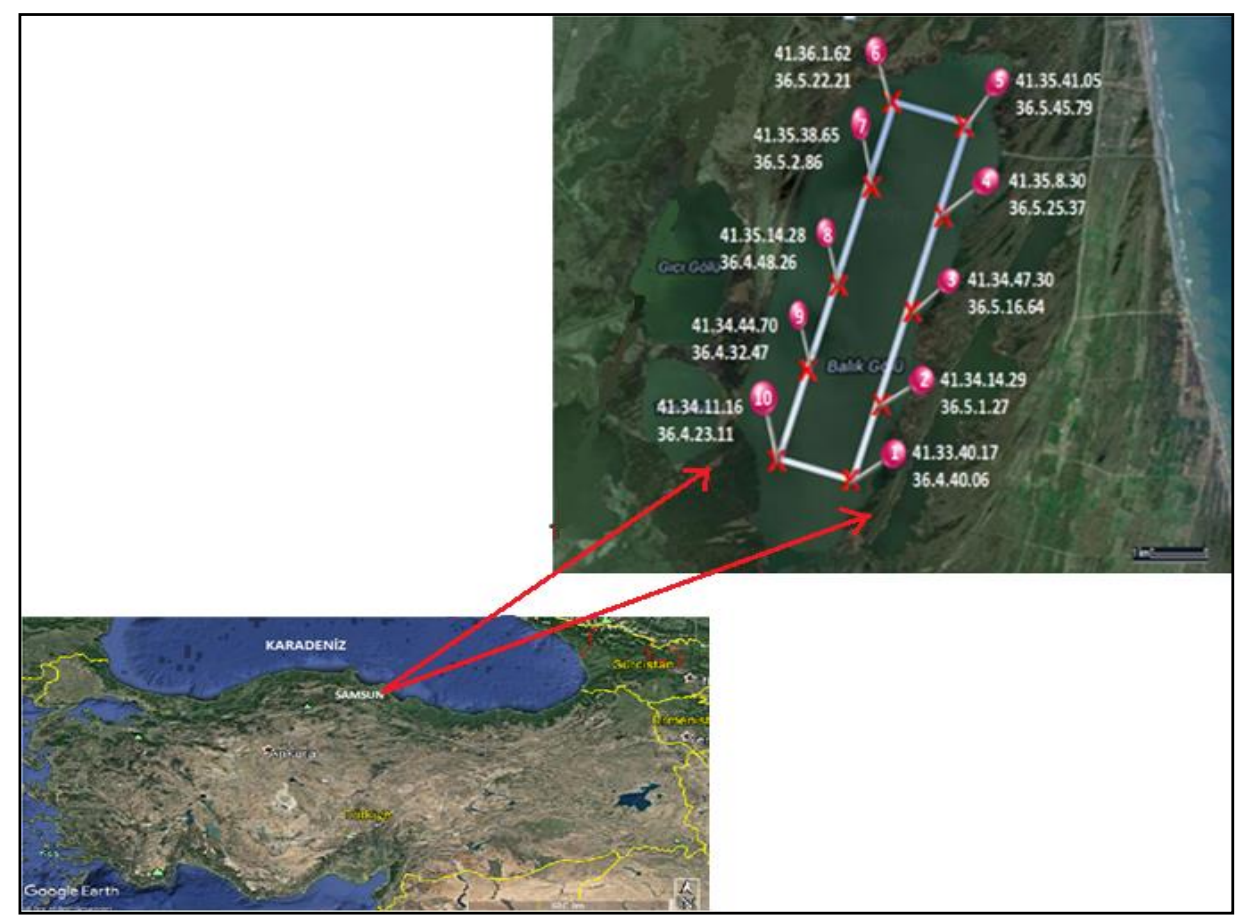

Şekil 1. Kızılırmak Deltası-Balık Gölü çalışma alanı ve su örnekleme noktaları

\subsection{Fiziksel ve Kimyasal Parametreler}

Balık gölü yüzeyinden alınan su örneklerinde arazide/anlık olarak, seki disk derinliği (SDD), sıcaklık, pH, elektriksel iletkenlik, çözünmüş oksijen, laboratuvar ortamında ise klorofil a, Renkli Çözünmüş Organik Madde (CDOM), toplam fosfor (TP), toplam azot (TN), TDS, tuzluluk ve bulanıklık analizleri gerçekleştirilmiştir. Laboratuvarda su örneklerinde, toplam azot "Su ve Atıksu Azotunun Belirlenmesinde Standart Yöntemler (Organik) Toplam azot yöntemi"

SM $4500 \mathrm{~N}$ ve toplam fosfor ölçümleri kit ile spektrofotometrik yöntemle DR 6000 marka spektrofotometre ile yapılmıştır. Sıcaklık, pH, ÇO, iletkenlik, TDS ve tuzluluk değerleri dijital yöntem esasına dayanan Hach Lange Marka HQ40D Model çoklu parametre ölçüm cihazı ile arazide anlık ölçülmüştür. Işık geçirgenliği, Seki disk derinliği arazide anlık olarak tespit edilmiștir. Bulanıklık, Hach Lange Marka 2100 Q (EPA) turbidimetre cihazı ile optik yöntem (NTU) kullanılarak laboratuvar ortamında ölçülmüștür.

Klorofil a, EPA 445.0 "In Vitro Determination of Chlorophyll a and Pheophytin a in Marine and Freshwater Algae by Fluorescence" metoduna ve renkli çözünmüş organik madde (CDOM) parametreleri Trilogy Laboratory Fluorometer model cihaz ile florometrik yöntemle belirlenmiştir. CDOM 
tayini için örnekler $0,22 \mu \mathrm{m}$ pore size'daki filtreden geçirilmiş ve filitrat florometre ile ölçülmüştür. Bütün su örneklerine ait analizler 24 saat içerisinde ve APHA, AWWA ve WEF standartlarına göre yapılmıștır (APHA ve WEF 2005).

\section{Sonuçlar}

Kızılırmak Deltası Balık gölü su kalitesi üzerine yapılan bu çalışmada 10 örnekleme noktasından ve yüzeyden 0,2-0,3 m derinlikten alınan su örneklerinde fizikokimyasal analizler yapılmıştır. Balık gölüne ait su kalite parametre değerleri Tablo 1'de verilmiştir. Parametrelerin mevsimsel değişimleri ise Şekil 2-6'da sunulmuştur. Bu çalışma kapsamında, Seki disk derinliği, klorofil a, bulanıklık, toplam fosfor, toplam azot, renkli çözünmüș organik madde parametrelerine ait değerleri, Yerüstü Su Kalitesi Yönetmeliğinde değişiklik yapılmasına dair yönetmelikte (2016) belirlenen eşik değerleri ile karşılaştırılarak su kalitesi belirlenmeye çalıșılmıștır. Ayrıca, hassas alan olan Balık gölünün trofik durumu (yaşam evresi) ve su kalitesindeki dönemsel değişiklik de belirlenmiştir.

\subsection{Su Kalitesinin Değerlendirilmesi}

$\mathrm{Su}$ sicaklığl, göl ekosistemi içerisindeki su organizmalarının biyolojik aktivitesini ve büyümesini büyük ölçüde etkiler. Yüksek sıcaklık değerleri normal şartlarda biyolojik aktiviteyi arttırmaktadır. Gölün sıcaklığı yaz boyunca daha yüksek ve kış döneminde en düşük değerlerde olmaktadır (Cunha vd., 2013). İlkbaharda, ortalama $19,27^{\circ} \mathrm{C}$; yaz mevsimi boyunca $28,84^{\circ} \mathrm{C}$, sonbaharda $18,74^{\circ} \mathrm{C}$ iken kış döneminde ise $10,71^{\circ} \mathrm{C}^{\prime}$ dir. pH aralığ $\mathrm{s}$ 8,46-8,69 arasında olup, dönemsel çok fazla değișim olmadığı belirlenmiștir. Gölün elektriksel iletkenlik değeri ortalama 1688,22 $\mu \mathrm{s} / \mathrm{cm}^{\prime}$ dir. Elektriksel iletkenliğin $\operatorname{arttığ~} \mathrm{k}$.Ş döneminde, yağışların artmasına bağlı olarak gölün suyu seviyesindeki yükselmeye bağlı olarak deniz suyu girișimini olduğu gözlenmektedir. Bulanıklık parametresi ise 19,89-62,56 NTU arasında değişmektedir. Özellikle yaz döneminde diğer dönemlere göre yaklaşık 2-3 kat artış olduğu görülmektedir. Seki disk derinliği (SDD), temel olarak, diskin yüzeyinden gelen ışığın yansımasının bir fonksiyonudur ve bu nedenle, sudaki partikül maddenin çözünme ve absorbsiyon özelliklerinden etkilenmektedir. Askıdaki maddelere bağlı olarak, ıșıklı tabakayı belirlemek için komplike olmayan bir indekstir. Genel olarak SDD, göldeki hem konumsal hem de zamansal değișimi göstermektedir (Saluja ve Garg 2017). SDD yaz aylarında yapılan örneklemelerde minimum, ilkbahar örneklemesinde maksimum değerine ulaşmıştır (Şekil 1). Bu çalışmada ortalama Balıkgölünün Seki Disk Derinliği, ortalama 0,36 m olup (Tablo 1), YSKY (2016)'ya göre hipertrofik su kalitesi $(<1 \mathrm{~m})$ sinıfına girmektedir.

Su içerisinde çözünen oksijen miktarı, suda yaşayan pek çok organizmanın solunum metabolizması için gereklidir ve birçok besin maddesinin çözünürlügünü ve kullanılabilirliğini etkilediğinden sudaki ekosistemlerin verimliliğini belirlemektedir. İç sulardaki oksijen dinamikleri; atmosferdeki girdiler, fotosentetik aktivite ve organik maddenin mikrobiyal ayrışması arasındaki dengeyle yönetilir (Saluja ve Garg 2017). Çözünmüş oksijen konsantrasyonu, sonbahar aylarında 11,07 mg/L ile en yüksek değeri; ilkbahar aylarında ise $9,65 \mathrm{mg} / \mathrm{L}$ ile en düşük değer olarak belirlenmiştir. Göldeki çözünmüş oksijen değeri ortalama $10,31 \mathrm{mg} / \mathrm{L}$ olup, mevsimsel döngüyü takip ettiği gözlenmiştir (Tablo 1). Gölün çözünmüş oksijen seviyesi, YSKY (2016)'ya göre oligotrofik su kalitesi (>7 m) sınıfını göstermektedir. İlkbahar aylarında çözünmüş oksijen değerinin daha düşük olmasının nedeni, organik maddenin bozunması, ayrıştırılması ve bakteriler tarafından solunması yoluyla serbest oksijenin kullanılmasına bağlı olabilir. Yaz aylarındaki sıcaklık artışına paralel olarak çözünmüş oksijen miktarı azalma göstermektedir (Rashidet vd., 2016). Ayrıca meteorolojik parametrelerden olan rüzgar hızının düşük olması da buna bağlı bir neden de olabilir Su ortamlarına azot, hem doğal hem de insan kökenli faaliyetler sonucu girmektedir. Su ortamına karışan azot bileşikleri birincil üretimi teşvik ederek ötrofikasyona neden olabilir. Ancak ötrofikasyonun asıl kaynağı fosforlu bileşiklerdir (Henry vd., 1984). Azotlu maddelerin kaynağı yağmur suyu ile taşınan atmosferik azot, toprak yapısında bulunan nitrat tuzları olabildiği gibi, tarımsal faaliyetler sırasında topraktan yıkanan, evsel ve endüstriyel atıklardan suya karışan bileşikler de olabilmektedir. Yağışlı iklimlerde, yağmur bitki örtüsü ve topraktan süzülürken akışın azot konsantrasyonu artmakta ve özellikle de nitrat azotu olarak akarsulara ve göllere ulaşmaktadır (Deemer vd., 2011). Ayrıca azot bağlayan mavi-yeşil alg ve bitkiler tarafından atmosferik azotun bağlanması da söz konusudur. Gölde Toplam Azot (TN) konsantrasyonu 4490-6070 $\mu \mathrm{g} / \mathrm{L} \quad$ arasinda değişmektedir. YSKY (2016)'ya göre değerlendirildiğinde ise göl ekosisteminde yıllık ortalama $4775 \mu \mathrm{g} / \mathrm{L}$ TN olup hipertrofik su kalitesi (>1500 $\mu \mathrm{g} / \mathrm{l})$ durumunu göstermektedir.

Fosfor, doğal suların verimliliğini etkileyen besleyici minerallerin de en önemlisidir. Doğal sularda toplam fosfor yoğunluğu; havzanın morfometresine, bölgenin jeolojik yapısının kimyasal içeriğine, suya karışan organik madde ve evsel atıklara özellikle deterjan olup olmamasına ve sudaki organik metabolizmaya bağlı olarak değișmektedir. Göllerde ve akarsularda çözünmüş inorganik fosfat, çözünmüş organik fosfat ve organik partiküler fosfat şeklinde bulunmaktadır. Çözünmüş inorganik fosfat fotoototrof üreticiler tarafından alınarak, organik olarak bağlandıktan sonra besin zincirine katılmaktadır (Schwörbel 1987). Fosfor su ortamında meydana gelen ötrofikasyonun da en temel elementidir (Harper 1992). TP değeri, tatlı su sistemlerinde verimliliğin belirlenmesinde baz alınan en önemli unsurlardan biridir. Yaz aylarında TP oranının yüksek olması gölün su seviyesinin düşmesi 
sonucunda meydana gelmektedir. Mikrobiyal aktivitelerin seviyesi sicaklığa bağlı olarak yükselmektedir. Bu nedenle yüksek sicaklıklarda sedimandan daha fazla miktarda fosfor salınımı gerçekleşmektedir. Fosfor konsantrasyoundaki artış, fitoplankton üretimindeki artışa ve alg patlamasına neden olmaktadır. Büyük miktarda çözünmüş oganik madde ve fitoplankton ayrışması nedeniyle göl ortamında yüksek değerlerde organik madde konsantrasyona sebebiyet vermektedir (Saluja ve Garg 2017). Buna bağlı olarak toplam fosfor (TP) değeri, kış döneminde en düşük (ortalama 57,95 $\mu \mathrm{g} / \mathrm{L}$ ), yaz büyüme döneminde ise TP $(115,27 \mu \mathrm{g} / \mathrm{L})$ değeri en yüksek olarak belirlenmiştir. YSKY (2016) yönetmeliğine göre, toplam fosfor seviyesine bağlı olarak, gölün ötrofik durumdan $(100 \mu \mathrm{g} / \mathrm{l})$ hipertrofik duruma (>100 $\mu \mathrm{g} / \mathrm{l})$ doğru geçtiği gözlenmektedir. Toplam fosfor miktarının yaz aylarında artmaktadır. Bunun sebebi ise, özellikle su sıcaklığının artması, tarımsal amaçlı gübre kullam miktarının artması ve gölün su seviyesindeki azalma olabilir. Klorofil-a konsantrasyonu, fitoplankton biyokütle konsantrasyonlarının değerlendirilmesine $1 s ̧ ı$ tutmaktadır.Gölde, Klorofil-a konsantrasyonu 22,76$68,61 \mu \mathrm{g} / \mathrm{L}$ aralığında ve ortalama değeri $28,07 \mu \mathrm{g} / \mathrm{L}$ olarak belirlenmiştir. Göl ortamındaki fitoplankton aktiviteleri ve düşük su seviyeleri nedeniyle klorofil-a konsantrasyonu yaz aylarında en yüksek seviyededir (Parparov ve Gal 2017). YSKY (2016) yönetmeliğine göre göl ekosisteminde klorofil a miktarına bağlı olarak hipertrofik koşulların (>25 $\mu \mathrm{g} / \mathrm{l})$ yaygın olduğu görülmektedir.

Tablo 1. Kızılırmak Deltası-Balık Gölü Su Kalite Parametre Değerleri (2017-2018)

\begin{tabular}{|c|c|c|c|c|c|}
\hline Parametre & $\begin{array}{l}\text { İlkbahar } \\
\text { Karışımı }\end{array}$ & $\begin{array}{l}\text { Yaz Büyüme } \\
\text { Dönemi }\end{array}$ & $\begin{array}{c}\text { Sonbahar } \\
\text { Karışımı }\end{array}$ & Kış Dönemi & Ortalama \\
\hline pH & 8,55 & 8,67 & 8,69 & 8,46 & 8,59 \\
\hline Sicaklık $\left({ }^{\circ} \mathrm{C}\right)$ & 19,27 & 28,84 & 18,74 & 10,71 & 19,39 \\
\hline Tuzluluk (\%o) & 0,80 & 0,81 & 0,93 & 0,98 & 0,88 \\
\hline TDS (mg/l) & 798,30 & 805,27 & 917,60 & 967,60 & 872,19 \\
\hline Çözünmüş Oksijen (mg/l) & 9,65 & 9,78 & 11,07 & 10,74 & 10,31 \\
\hline $\begin{array}{c}\text { Elektriksel İletkenlik } \\
(\mu \mathrm{s} / \mathrm{cm})\end{array}$ & 1548,27 & 1561,00 & 1771,20 & 1872,40 & 1688,22 \\
\hline Bulanıklık (NTU) & 24,84 & 62,56 & 37,95 & 19,89 & 36,31 \\
\hline $\operatorname{CDOM}(\mu \mathrm{g} / \mathrm{L})$ & 80,44 & 79,33 & 57,50 & 62,49 & 69,94 \\
\hline Seki Disk Derinliği (m) & 0,43 & 0,24 & 0,30 & 0,48 & 0,36 \\
\hline Klorofil-a $(\mu \mathrm{g} / \mathrm{L})$ & 45,13 & 68,61 & 48,86 & 22,76 & 46,34 \\
\hline Toplam Azot $(\mu \mathrm{g} / \mathrm{L})$ & 6070 & 4560 & 4490 & 3980 & 4775 \\
\hline Toplam Fosfor $(\mu \mathrm{g} / \mathrm{L})$ & 70,00 & 115,27 & 82,4 & 57,95 & 81,41 \\
\hline
\end{tabular}

Not: Su kalite parametrelerine ait aylık olarak, 10 örnekleme istasyonuna ait değerlerin ortalaması

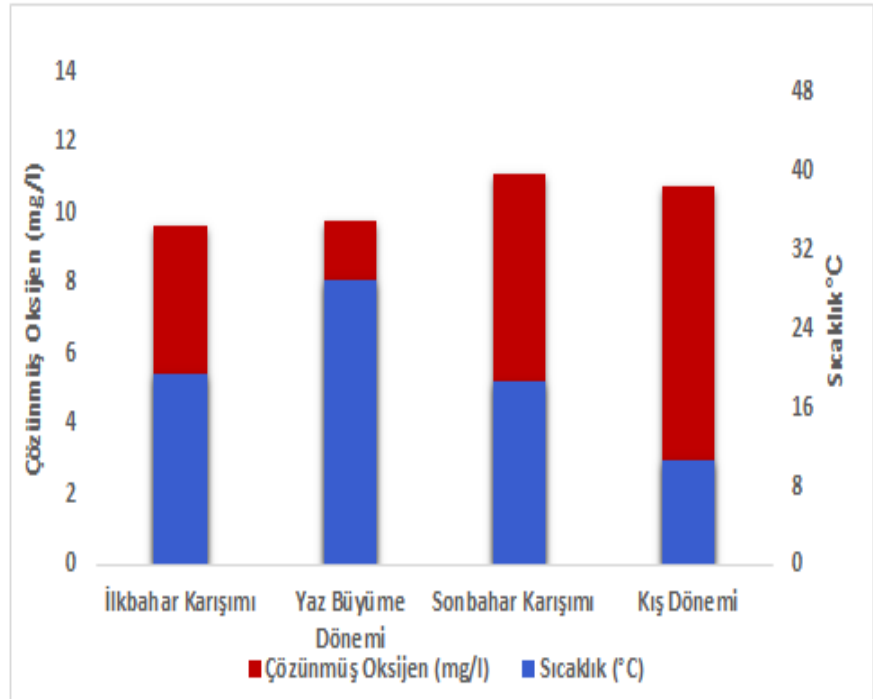

Şekil 2. Balık Gölü'nün mevsimsel değişime bağlı olarak Çözünmüş Oksijen ve Sıcaklık Değerleri 


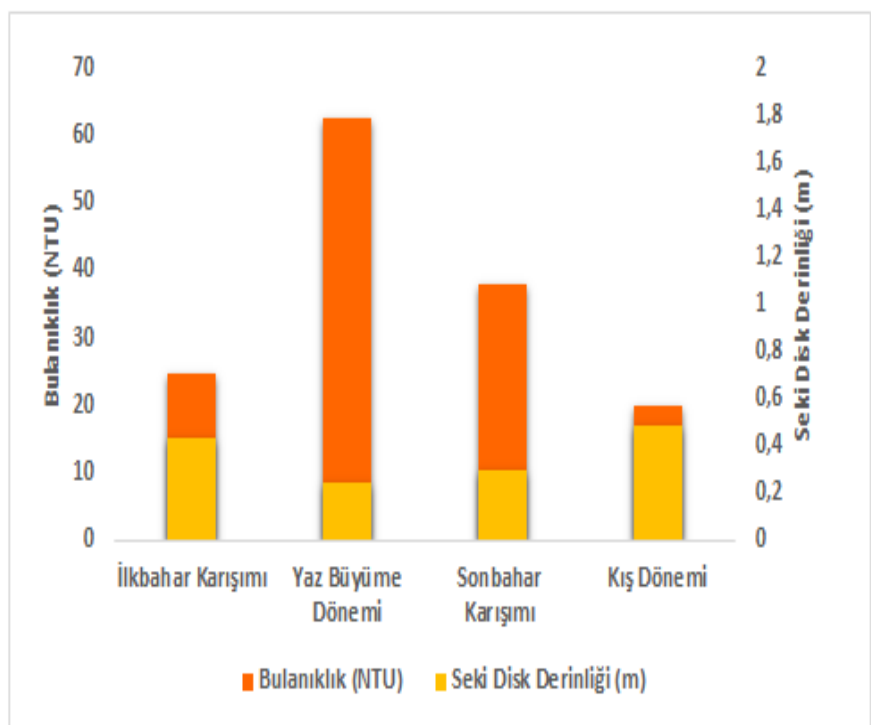

Şekil 3. Balık Gölü’nün mevsimsel değişime bağlı olarak Bulanıklık ve Seki Disk Derinliği Değerleri

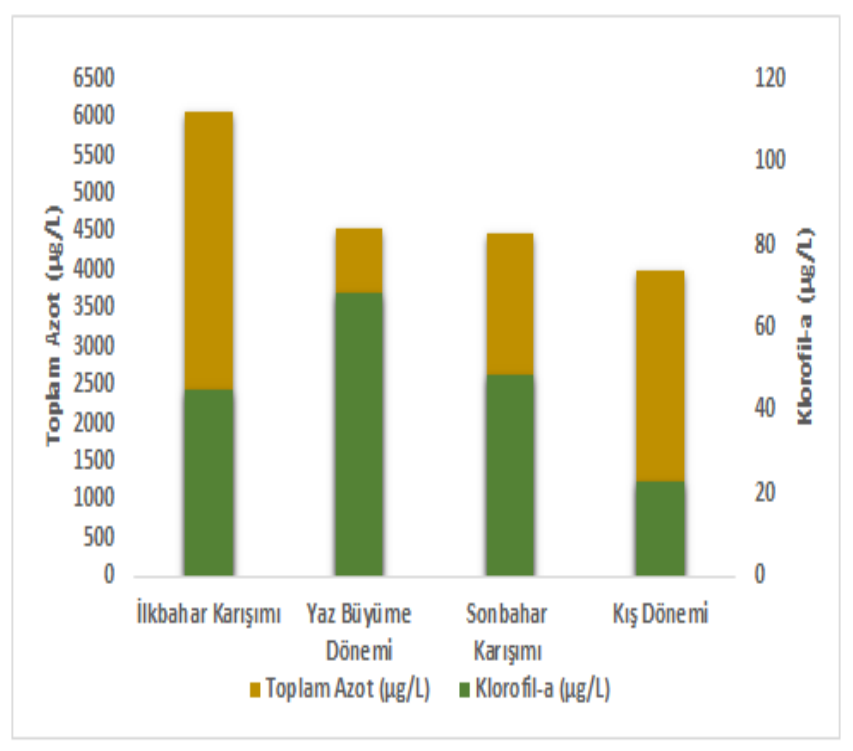

Şekil 4. Balık Gölü'nün mevsimsel değişime bağlı olarak Toplam Azot ve Klorofil-a Değerleri

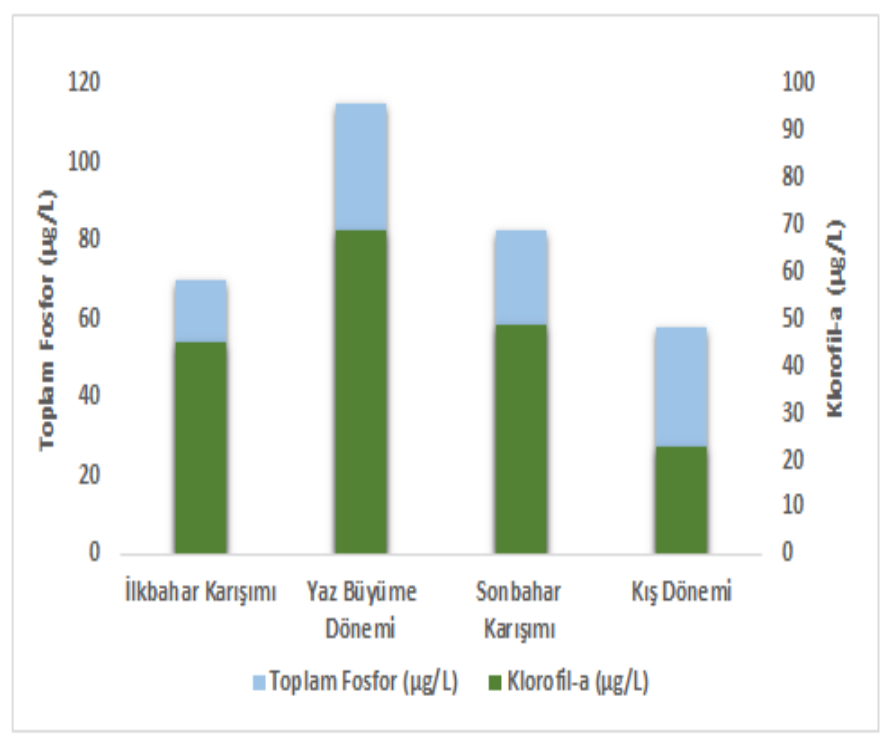

Şekil 5. Balık Gölü’nün mevsimsel değişime bağlı olarak Toplam Fosfor ve Klorofil-a Değerleri 


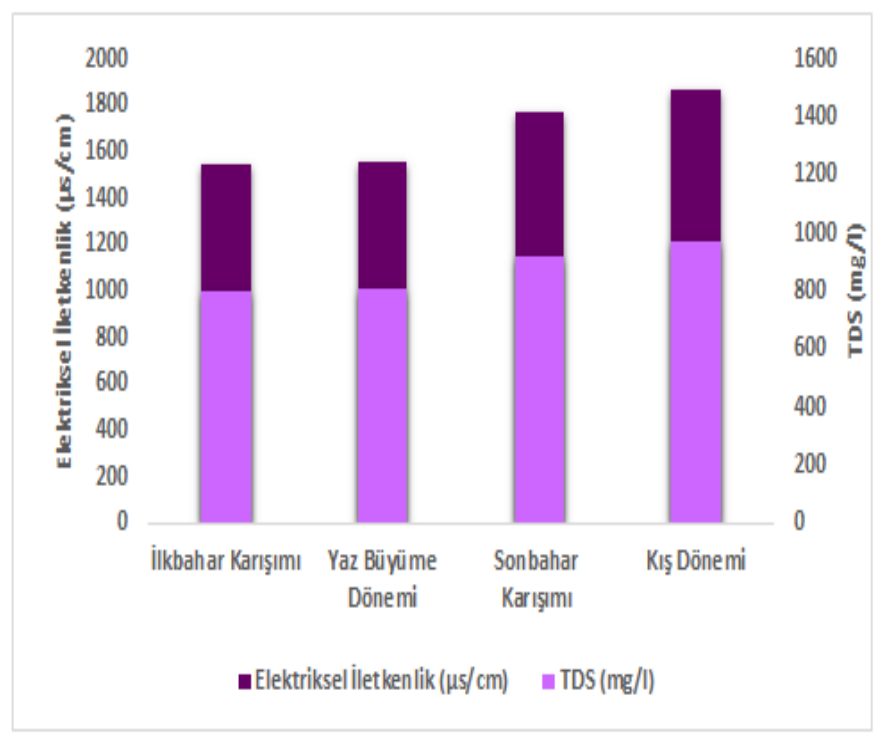

Şekil 6. Balık Gölü'nün mevsimsel değişime bağlı olarak Elektiriksel İletkenlik ve TDS Değerleri

\subsection{Trofik Durum İndeksi}

Göller, bölgesel hidrolojiye ve bozulmamış biyolojik çeşitliliğe katkıda bulunan hassas bir ekosistemdir ve bağımlı nüfusun sosyo-ekonomisini sürdürmede önemli rol oynamaktadır (Rashid vd., 2017). Göllerin su kalitesi özellikleri, göllerin rekreasyonel kullanımı dahil olmak üzere; habitat ve tür çeşitliliğinin belirlenmesinde kritik faktörleri temsil etmektedir (Fuller ve Jodoin 2016). Göllerin sinıflandırılması ve bunların trofik durumlarını belirlemek için çeşitli yöntemler benimsenmiştir. En yaygın kullanılan ve yaygın olarak kullanılan yöntem üretkenliğe dayanmaktadır. En sık kullanılan biyokütle ile ilişkili trofik durum Carlson (1977) indeksidir. Trofik durum indeksi, su kalitesi çalışmalarının önemli bir parçasıdır ve su kalitesi değişkenlerine bağlı olarak birden fazla parametreyi barındırdığı için; bir gölün su kalitesinin analiz edilmesi, hesaplanması ve yorumlanmasına kolaylık sağlamaktadır (Cunha vd., 2013). Trofik besin ilaveleri, zorlayıcı faktörlere biyolojik cevap olarak anlaşılmaktadır, ancak besin maddesi etkisi mevsimsel değişim, karıştırma derinliği gibi parametrelerle de değișebilmektedir. Göl suyunun kalitesinin derecelendirmesi için Trofik Durum İndeksi (Trophic State Index: TSI); Klorofil $a$ ( $\mathrm{Chl} a$ ), toplam fosfor (TP), toplam azot (TN) ve seki disk derinliği (SDD) parametreleri kullanılarak hesaplanmaktadır (Tablo 2) (Carlson 1977; Kratzer ve Brezonik 1981). Yapılan bu parametrelere ait ölçümlerin birimleri ve değerleri farklı boyutta olduğu için bu parametreleri birbirleri ile kıyaslamak ve sınırlayıcı parametreyi tespit etmek zor olmaktadır. Tablo 3'de Göllerin trofik durumunun sinıflandırılması ve TSI sınır değerleri verilmektedir (Carlson 1977). Bu indeks bize bir gölü farklı parametreler açısından tüm parametreleri ortak bir ölçekte değerlendirebilme şansı vermektedir (Akyüz 2016).
Bu çalışmada, aylık olarak Nisan 2017-Nisan 2018 tarihleri arasında alınan göl yüzey suyunda, toplam azot (TN), toplam fosfor (TP), klorofil-a (Chl-a) ve Seki Disk Derinliğinin (SDD) mevsimsel değișimine bağlı olarak, bu parametreler arasındaki ilișkiye göre Carlson 1977) ; Kratzer and Brezonik (1981) Trofik Durum İndeksi (TSi) değerleri hesaplanarak değerlendirilmiştir. Buna göre, Balık Gölü'nün trofik durum indeksi mevsimsel olarak değişimi hesaplanmış ve Tablo 4'de verilmektedir. Balık gölü ylllık ortalama trofik seviye indeks değerleri; TSi (Chla) 67,5; TSİ (SDD) 76,2; TSI (TN) 176,5; TSİ (TP) 67,1 'dir. Gölün özellikle yaz büyüme döneminde, TSI (Chl-a) 72,08; TSI (SDD) 80,56; TSI (TP) 72,6;, TSI (TN) 176,02 değerleri oldukça yüksek olup, diğer mevsimlerde de yaygın olarak hipertrofik durum görülmektedir. Bu nedenle gölde, alg ve makrofit yoğunlu fazla ve ışık geçirgenliği sinırlıdır. Ayrıca, mevsimsel değişimlere bağlı olarak TP ve SDD trofik seviye indeksi değerlerine göre göl ekosistemi hipertrofik (TSİ, 70-80), TN ve Chl-a değerlerine göre ise ötrofik-hipertrofik durumun (TSİ, 60-70) belirgin olduğu görülmektedir. Cüce ve Bakan (2017)'nın Balık Gölü'nde yaptığı çalışmada genel olarak gölün ötrofik yapıda olduğu ve göl statüsünün kritik duruma olduğunu belirlemiş̧leridir. Sonuç olarak, bu çalışmada ise mevsimsel değişimlere bağlı olarak, elde edilen sonuçlar, TP, TN, SDD ve Chl-a'nın trofik seviye indeks değerlerine göre, TSI sinıflandırmasına göre ötrofik durumun sınır değerini aşmakta olduğu (TSI 60-70), yaygın olarak hipertrofik durumun oluşması nedeniyle gölün kritik durumda olduğunu ortaya koymaktadır. 
Tablo 2. Trofik durum indeks değerinin hesaplanması (Carlson 1977; Kratzer ve Brezonik 1981)

\begin{tabular}{cc}
\hline Trofik Durum İndeksi & Trofik Durum İndeks Değerinin Hesaplanması \\
\hline TSI (Chl-a) & $9,81^{*} \ln (\mathrm{Chl}-\mathrm{a})+30,6$ \\
TSI (SDD) & $60-14,41^{*} \ln (\mathrm{SDD})$ \\
TSI (TP) & $14,42^{*} \ln (\mathrm{TP})+4,15$ \\
TSI (TN) & $54,45+14,43^{*} \ln (\mathrm{TN})$ \\
\hline
\end{tabular}

*TSI Carlson tarafından ilk kez tanımlandığında TP, Chl-a ve SDD değerlerine göre hesaplanırken,Kratzer ve Brezonik'in yaptığı çalışma (1981) ile TN değeri de ilave edilmiştir.

Tablo 3. Göllerin trofik durumunun sınıflandırılması ve TSI sınır değerleri (Carlson 1977)

\begin{tabular}{|c|c|c|c|c|}
\hline TSI & $\begin{array}{l}\text { Chl-a } \\
(\mu g / L)\end{array}$ & $\begin{array}{l}\text { SDD } \\
(\mathrm{m})\end{array}$ & $\begin{array}{l}\text { TP } \\
(\mu g / L) \\
\end{array}$ & Özelliği \\
\hline$<30$ & $<0,95$ & $>8$ & $<6$ & Oligotrofik: Temiz su, $\mathrm{O}_{2}$, yll boyunca hipolimnion durumu mevcut \\
\hline $30-40$ & $0,95-2,6$ & $8-4$ & $6-12$ & Sığ göllerin hipolimnion tabakası oksijensiz olabilir \\
\hline $40-50$ & $2,6-7,3$ & $4-2$ & $12-24$ & $\begin{array}{l}\text { Mezotrofik: Su kısmen temiz, yaz süresince hipolimniondaki } \\
\text { oksijensizlik artıș gösterebilir }\end{array}$ \\
\hline $50-60$ & $7,3-20$ & $2-1$ & $24-48$ & Ötrofik: Hipolimnion oksijensiz, makrofit problemleri de gözlenebilir \\
\hline $60-70$ & $20-56$ & $0,5-1$ & $48-96$ & $\begin{array}{l}\text { Mavi-yesil algler dominanttır, alg köpükleri ve makrofitler sorun } \\
\text { teşkil edebilir. }\end{array}$ \\
\hline $70-80$ & $56-155$ & $\begin{array}{l}0,25- \\
0,5\end{array}$ & $96-192$ & Hipertrofik: Işık verimliliği sınırlar. Algler ve makrofitler yoğundur \\
\hline$>80$ & $>155$ & $<0,25$ & $\begin{array}{l}192- \\
384\end{array}$ & Alg köpükleri ve az sayıda makrofit mevcuttur \\
\hline
\end{tabular}

Tablo 4: Balık Gölün Trofik Durum İndeksi Değerleri

\begin{tabular}{cccccc}
\hline $\begin{array}{c}\text { Trofik Durum İndeksi } \\
\text { (TSİ) }\end{array}$ & $\begin{array}{c}\text { İlkbahar } \\
\text { Karışımı }\end{array}$ & $\begin{array}{c}\text { Yaz Büyüme } \\
\text { Dönemi }\end{array}$ & $\begin{array}{c}\text { Sonbahar } \\
\text { Karışımı }\end{array}$ & $\begin{array}{c}\text { Kış } \\
\text { Dönemi }\end{array}$ & $\begin{array}{c}\text { Ortalama } \\
\text { Değerleri }\end{array}$ \\
\hline TSİ (Chl-a) & 67,97 & 72,08 & 68,75 & 61,25 & $\mathbf{6 7 , 5}$ \\
TSİ (SDD) & 72,16 & 80,56 & 77,34 & 74,72 & $\mathbf{7 6 , 2}$ \\
TSİ (TP) & 65,41 & 72,61 & 67,76 & 62,68 & $\mathbf{6 7 , 1}$ \\
TSİ (TN) & 180,15 & 176,02 & 175,80 & 174,06 & $\mathbf{1 7 6 , 5}$ \\
\hline
\end{tabular}

\subsection{Kalite ve Kontrol}

Laboratuvar analizleri sonucunda göl su örneklerinden elde edilen parametre değerleri ve örnekleme istasyonlarına ait koordinat bilgileri kayıt altına alınmıştır. Analizler/ölçümler \% 90-95 güven aralığında yapılmıştır. Rölatif hata oranı \%10'dan büyük olması durumunda analizler tekrarlanmıştır. Ayrıca, ilk set analizlerde kalitenin sağlanması ve kontrolü amaciyla her 5 numunede bir kör numune analizi, her 10 numunede bir içeriği bilinen bir laboratuvar kontrol numunesi ile kontroller yapılmış ve sonuçların tatminkar olması durumunda kontrol numunesi sıklığı azaltılmıştır.

\section{Tartışma}

$\mathrm{Bu}$ çalışmada, Kızılırmak Deltası gibi uluslararası koruma statüsü içerisinde bulunan en büyük göllerden biri olan Balık Gölünün su kalitesini izleme çalışmaları yürütülmüş ve gölün trofik durumu belirlenmeye çalışılmıştır. Bir su kaynağının amacına uygun olarak kullanılabilmesi için periyodik olarak izlenmesi gerekmektedir. RAMSAR alanı olarak belirlenip koruma altına alınmış olan Kızılırmak Deltası-Balık Gölü 2017--2018 dönemlerini kapsayan süreçte, aylık olarak su kalitesinin fizikokimyasal parametreleri ve trofik durum indeksi belirlenmeye çalışılmıştır.

Bu çalışmadan elde edilen sonuçlara göre; gölün su kalitesine bağlı olarak zamansal değişimlerinin önemli olduğu ve özellikle yaz aylarında göldeki su seviyesinin düşmesine bağlı olarak ekosistemi önemli olarak olumsuz etkilediği görülmektedir. Antropojenik faaliyetler göl ekosisteminde değişikliklere neden olmuştur. Biyolojik içerikli kirletici deşarjları, ticari amaçlı balık avı ve yabancı türlerin girișimi ile insan etkisine maruz kalmıștır. Yerüstü Su Kalitesi Yönetmelik (2016)'ine göre ve 
Trofik Seviye İndeksine (Carlson 1977) göre, Balık gölü ekosisteminde hipertrofik koşulların yaygın olduğu gözlemlenmektedir. Bunun en önemli sebebi ise, evsel atık sular ile tarımsal faaliyetlerdeki azotlu ve fosforlu gübre kullanımı sebebiyle ortaya çıkan organik ve inorganik madde yüklemeleridir. Arazi kullanımındaki değişiklikler, sulama ile drenaj kanallarındaki yenilikler ve balıkçılık benzeri faaliyetler de deltadaki sulak alanları doğrudan etkileyerek ekosistem içerisindeki biyoçeşitlilik yok olma tehlikesi ile karşı karşıya getirmektedir. Bu nedenle özellikle sulak alanlardaki kirlenme kaynaklı tehlikelerin sistematik bir şekilde izlenmesi, tespit edilmesi durumunda vakit geçirmeden gerekli müdahalenin ve/veya önlemlerin alınması, geleceğe dair planlamaların yapılması benzer doğa güzelliklerinin korunması açısından önem arz etmektedir. Öte yandan, hassas su kütlesi olan ve özel korunan alan statüsündeki Balık gölü'nün farklı koruma önlemlerinin alınması ve izleme yükümlülüklerinin de yerine getirilmesi gerekmektedir. $\mathrm{Bu}$ amaç doğrultusunda ekolojik ve kimyasal durumun tespiti için fizikokimyasal, kimyasal, biyolojik ve hidro-morfolojik parametrelerin birlikte değerlendirilerek, baskıların/etkilerin belirlenmesi ve iyileştirilme çalışmalarının gerçekleştirilmesi gerekmektedir.

\section{Teşekkür}

$\mathrm{Bu}$ çalışma, Ondokuz Mayıs Üniversitesi tarafından, PYO.HUBF.1901.16.001 referans numaralı bilimsel araştırma projesi ile desteklenmiştir.

\section{Conflict of Interest / Çıkar Çatışması}

Yazarlar tarafından herhangi bir çıkar çatışması beyan edilmemiştir.

No conflict of interest was declared by the authors.

\section{Kaynaklar}

Akyüz, D.E., 2016. Trofik Durum İndeksi ile Anahtar Sinırlayıcı Parametrelerin Değerlendirilmesi: Taihu Gölü Örneği. Mehmet Akif Ersoy Üniversitesi Fen Bilimleri Enstitüsü Dergisi 7 (Ek Sayı 1), 194201.

APHA, AWWA, WEF, (2005). Standard Methods for the Examination of Water and Wastewater (21th Ed). Washington, DC: American Public Health Association.

Carlson, R. E., Simpson, J., 1996. A coordinator's guide to volunteer Lake monitoring methods. Madison: North American Lake Management Society.

Carlson, R.E., 1977. A trophic state index for lakes. Limnology and Oceanography, 22, 361-369.
Cunha D.G.F., Calijuri M. C., Lamparelli M.C., 2013. A trophic state index for tropical/subtropical reservoirs (TSItsr). Ecological Engineering, 60, 126- 134.

Cüce, H. ve Bakan, G., 2017. Siğ Bir Gölde Sediman Kalitesinin Trofik Duruma Etkisinin Değerlendirilmesi; Balik Gölü Örneği (Kizilirmak Deltasi), Ordu Üniv. Bil. Tek. Derg., Cilt:7, Sayı:1, 2017,83-97.

Deemer, B. R., Harrison J.A., Whitling, E.W., 2011. Microbial dinitrogen and nitrous oxide production in a small eutrophic reservoir: An in situ approach to quantifying hypolimnetic process rates, Limnology and Oceanography 56(4): 1189-1199.

Harper, D., 1992. Eutrophication of fresh waters: Principles, problems and restoration. Chapman and Hall, London, UK.

Henry. R., Tundisi, J.G., Curi, P.R., 1984. Effects of phosphorus and nitrogen enrichment on the phytoplankton in a tropical reservoir. Hydrobiologia, 118, 177-85.

Jeppesen, E., Sondergaard, M., Jensen, J.P., Mortensen, E., Hansen, A.M. and Jorgensen, T., 1998. Cascading Trophic Interactions from Fish to Bacteria and Nutrients after Reduced Sewage Loading: An 18Year Study of a Shallow Hypertrophic Lake, Ecosystems, 1, 250-267.

Kratzer, C.R., and Brezonik, P.L., 1981. A Carlson-type Trophic State Index for Nitrogen in Florida lakes. Water Res. Bull., Am. Water Res. Assn. 17(4), 713715, 1057-1060.

SKDYP 2019-2023. Samsun Kızılırmak Deltası Sulak Alan ve Kuş Cenneti Doğal Sit Alanaları Yönetim Planları. Çevre ve Şehircilik Bakanlığı.

Le, C. Zha, Y., Li, Y. Sun, D. Lu, H. Yin, B., 2010. Eutrophication of Lake Waters in China: Cost Causes, and Control. Environmental Management 45, 662-668 DOI 10.1007/s00267-010-9440-3.

Parparov, A., Gal, G., 2017. Quantifying Ecological Stability: From Community to the Lake Ecosystem. Ecosystems, 20, 1015-1028. DOI: 10.1007/s10021-016-0090-z.

Samsun Kızılırmak Deltasi Doğal Sit Alanlari Sulak Alan ve Kuş Cenneti (2019-2023) Yönetim Planı, Çevre ve Şehircilik Bakanliği Tabiat Varliklarini Koruma Genel Müdürlüğü, Ankara.

Saluja, R., Garg, J.K., 2017. Trophic state assessment of Bhindawas Lake, Haryana, India. Environment Monitoring Assessment 189, 32. DOI 10.1007/s10661-016-5735-z. 
Schwörbel, J., 1987. Einführung in die Limnologie. Gustav Fischer Verlag, 269 p, Stuttgart.

Sulak Alanlar, 2013. Orman ve Su İşleri Bakanlığı, Doğa Koruma ve Milli Parklar Genel Müdürlüğ̈̈, Hassas Alanlar Dairesi Başkanlığı, Sulak Alanlar Şube Müdürlüğü, Ankara.

U.S.EPA, 2010. National Lakes Assessment: Technical appendix data analysis approach. EPA/841/R/09/001a. U.S. Environmental Protection Agency, Office of Water and Office of Research and Development.

Water Framework Directive (WFD) 2000/60/EC: Directive 2000/60/EC of the European Parliament and of the Council of 23 October 2000 establishing a framework for Community action in the field of water policy.

Yerüstü Su Kalitesi Yönetmeliği (YSKY) (2012;2016). 30.11.2012, Sayı: 28483; Sayı : 29797.

Yeniyurt, C., Hemmami, M., CCağırankaya, S., Koopmanschap E. 2011. Türkiye'nin Ramsar Alanlarında Sulak Alan Yönetim Planları Değerlendirme Raporu. Doğa Derneği, Ankara, Türkiye. 